\title{
O PRIVILÉGIO. AS DUAS TEORIAS FREUDIANAS DO ORIGINÁRIO SOCIAL
}

\author{
Jacques André* \\ Tradução \\ Gustavo Adolfo Ramos Mello Neto \#
}

RESUMO. Neste artigo, o professor Jacques André busca “fazer trabalhar” a teoria freudiana da horda originária. Isto quer dizer que, de um lado, ele mostra suas simplificações e carências e, de outro, ele a conduz até suas possíveis conseqüências e variantes. Tal percurso através da obra freudiana permitirá ao autor reconhecer a existência de uma segunda teoria da horda originária em Freud, inconciliável com a primeira - a mais conhecida - aquela de Totem e Tabu ( $\mathrm{O}$ tradutor).

Palavras-chave: Psicanálise, sociedade, horda primária.

\section{THE PRIVILEGE. TWO FREUDIAN THEORIES OF THE ORIGINAL SOCIAL}

\begin{abstract}
In this article, Professor Jacques André seeks to "make it work" (criticize/interpret) the Freudian theory of the original (primary) horde. That means, on one side, he shows its lacks and simplifications and, on the other, he drives it up to its possible consequences and variants. Such journey through the Freudian work will allow the author the existence of a second theory of the original horde in Freud, incompatible with the first - the best known - the Totem and Taboo theory.
\end{abstract}

Key words: Psychoanalysis, society, , primary horde.

* Psicanalista e professor da Université Denis Diderot - Paris VII, França.

Endereço para correspondência: Departamento de Psicologia, Universidade Estadual de Maringá, Av. Colombo, 5790, CEP 87020-900, Maringá-Paraná. At. Gustavo Adolfo Ramos Mello Neto.

\# Professor do Departamento de Psicologia da Universidade Estadual de Maringá.

\begin{tabular}{|l|l|l|l|l|l|}
\hline Psicologia em Estudo & DP/CCH/UEM & v. 5 & n. 1 & p. 1-34 & 2000 \\
\hline
\end{tabular}


"O homem é um animal de horda".

Freud o afirma, não em Totem e Tabu ou em algum outro texto onde ele retoma a hipótese da horda originária, mas ao refletir sobre as sociedades que lhe são contemporâneas, mais precisamente a propósito de um fenômeno que, nos anos 20, promete um futuro temeroso: a multidão ${ }^{1}$.

Se a "psicologia individual é também, a principio e simultaneamente, uma psicologia social"2, é preciso daí aceitar uma conseqüência: da mesma forma que o homem é habitado pela criança que ele foi um dia, as sociedades de hoje devem levar em seu seio o testemunho dos primeiros tempos. Um dos últimos capítulos de Psicologia de massas e análise do eu intitula-se: "a massa e a horda primordial". Nele Freud reencontra, à maneira da análise de massas de sua época, no par formado pela multidão e por seu líder, os componentes mínimos do que ele pode descrever como sendo o primeiro estado social, a horda e o pai todo-poderoso.

É algo vão questionar a verdade da tese da horda originária: as coisas realmente começaram assim? É inútil relembrar a multiplicidade de argumentos, uns mais fundamentados que os outros, que podem ser colocados contra essa tese: estamos, aí, no absolutamente não verificável.

Um outro aporte possível, também pertinente, consiste em questionar o presentea ou um passado suficientemente acessível: se a teoria freudiana da origem do estado de sociedade tem alguma validade, deve ser possível confrontá-la com a análise das sociedades reais - uma vez considerada como aceita a idéia de que o originário se encontra no fundamento das formações individuais ou coletivas ulteriores, se não do mesmo modo, pelo menos sob a máscara de suas transformações. Freud, mesmo, não faz outra coisa em Psicologia de massas e análise do eu, e ninguém se espantará se é ele mesmo quem confirma o fundamento da própria construção, mas não podemos, evidentemente, contentar-nos apenas com essa auto-estimativa. Um indicador histórico justifica por si só que se tome em consideração a hipótese freudiana: matam-se realmente os chefes (de Estado), mesmo que raramente os comam (Lumumba é talvez o último homem político que preencheu essas duas condições).

S. Freud. Psychologie des foules et analyse du moi (1981[1921]), p. 188.

2 Ibid, p. 213. 
À vista desse vasto programa ${ }^{3}$, o presente artigo limita-se aos prolegômenos e, quando nele for evocada a teoria freudiana do originário social, é logicamente para lembrar a narrativa do capitulo IV de Totem e tabu: a horda, o pai, os irmãos, o homicídio, a devoração, a nostalgia mesclada à culpabilidade. Eventualmente, serão criticadas as simplificações, as carências desse cenário. Antes de concluir será preciso, ainda , levar até as últimas conseqüências a argumentação de Freud.

Minha preocupação, aqui, é dupla: reler, primeiramente, a versão Totem e tabu, sobre a aparição do estado de sociedade e, em seguida, percorrer as variantes desta primeira versão, tal como elas ressurgem na obra de Freud, até Moisés e a religião monoteísta. A releitura inicial mostrará o antagonismo "solidário" da homossexualidade e do ódio ao feminino, e o percurso das variantes permitirá reconhecer o esboço de uma segunda teoria, mais que diferente, inconciliável com a primeira, e não simplesmente feita de remanejamentos da hipótese de partida.

\section{I - O PAI E OS FILHOS MAIS VELHOS}

Totem e tabu, todas as primeiras páginas.

Tomemos, diz Freud ${ }^{4}$, o exemplo dos mais primitivos entre os primitivos, esses selvagens-atrasados-miseráveis habitantes do interior do continente australiano - um continente cuja fauna conservou tantos traços arcaicos. Eles não edificam, nem cultivam, não domesticam animais, nem mesmo um cachorro. Nem falemos da arte da cerâmica, pois ela lhes é totalmente desconhecida. Sua única atividade: alimentam-se da carne de animais, de qualquer um que lhes caia entre os dentes, e de raízes arrancadas à terra. O que se pode esperar da sexualidade desses "miseráveis canibais nus", senão uma vida instintual que nada limite... E, pois bem, não é isso! É mesmo o inverso :

eles se impõem a mais rigorosa interdição das relações sexuais. Parece mesmo que toda a sua organização

3 Um programa que não é virgem de toda tentativa. Entre os textos mais recentes tratando desse problema, citamos: S. Moscovici, L'âge des foules (1981) e E. Enriquez, De la horde primitive à l'état (1983).

4 S. Freud. Totem et tabou (1912 [1947]); designado, neste artigo, por T \& T. 
social é subordinada a essa intenção ou ligada à sua realização (...) (T\&T, p. 10).

Esses selvagens parecem obcecados por um horror excessivamente pronunciado ao incesto e possuem grande sensibilidade às relações incestuosas (T\&T p. 14).

Apesar de mais próximo da fauna do que da humanidade ${ }^{5}$, esse canibal nu é um homem: o incesto lhe causa horror.

Totem e tabu, último capítulo.

Após ter passado longamente em revista um material sobretudo etnológico, Freud formula a sua hipótese, o próprio cenário do nascimento da vida em sociedade. Em que se transformaram, então, o incesto e o medo que ele inspira?

Os dois tabus do totemismo [concernentes ao incesto e ao parricídio] pelos quais principia a moral humana não têm o mesmo valor psicológico. Só a atitude respeitosa em relação ao animal totêmico repousa (inteiramente ${ }^{* * *}$ ) sobre os impulsos afetivos: o pai está morto e por isso não há praticamente mais nada a fazer. Mas, o outro tabu, a interdição do incesto, tinha também uma grande importância prática [evitar a divisão, a guerra] (T\&T, p. 165; entre colchetes: meus apontamentos).

5 Segundo os níveis da argumentação e as necessidades da demonstração, Freud adota em face do "primitivo" pontos de vista divergentes. Aqui o primitivo é um selvagem, só a interdição do incesto atesta a sua pertinência ao gênero humano. Em outro lugar, confrontado à dispersão dos fatos reunidos no único capítulo sobre o totemismo, Freud escreve "os povos primitivos, longe de serem povos jovens, são tão velhos como os povos civilizados (...) não se deve esperar que suas idéias e suas instituições primitivas tenham sido conservadas intactas e sem a menor deformação até os nossos dias" "O estabelecimento do estado primitivo fica, assim, sempre como uma espécie de construção" ( $T$ \& T, p. 120, nota 2).

*** A tradução francesa economiza (infelizmente) um ganz. Ocorre, contudo, que uma má tradução não é inteiramente sem mérito: o que caracteriza, com efeito, o incesto, nesse fim de Totem e tabu, é a sua total ausência no registro dos afetos, para estar presente apenas no domínio do social, do prático. 
No princípio eram o temor e o horror, e ao termo do percurso há sobretudo uma disposição prática, um interdito de menor valor psicológico, repousando apenas em parte sobre os impulsos afetivos. Um crime expulsa ${ }^{a}$ o outro: o parricídio tomou todo o espaço.

Que ocorreu nesse intervalo? Notemos, por enquanto, apenas esta notável coincidência: é no próprio lugar onde surge a hipótese da horda que desaparece o incesto como questão (como compreender que o que é objeto de desejo possa, ao mesmo tempo, engendrar o horror?). Depois de haver passado em revista e descartado um a um os argumentos geralmente utilizados para explicar o medo e o interdito, Freud, longe de nos propor uma análise enfim satisfatória, confessa nada saber sobre isso - indo, mesmo, até a uma certa paralisia da investigação:

Vemo-nos obrigados, ao fim da análise, a subscrever a confissão de Frazer: ignoramos a origem do horror ao incesto e não sabemos mesmo em que direção procurá-la (T\&T, p. 144-145).

Precisamente neste lugar, Freud troca a sua perplexidade por uma hipótese que logo irá tomar a forma acabada de uma teoria. A troca é anódina, sub-reptícia: "devo ainda mencionar..."(T\&T, p. 145), e o que segue não o é, nem um pouco: a horda e seu destino. O medo ao incesto, enquanto tal, desaparece; ele não é mais que um medo conseqüente: medo do macho dominante, de suas represálias castradoras. Dessa forma, o que barra o incesto não é senão um impedimento de fato, que, com o tempo, interioriza-se pouco a pouco em proibição.

Por que essa desvalorização do incesto, e a qual necessidade ela responde? Tantas questões, tantos indícios na origem de nossa leitura...

\section{Nem mãe, nem incesto}

Atendo-se à tese central de Totem e tabu, aquela que nos conduz da horda primitiva ao estado de sociedade, passando pelo assassinato do pai e o banquete canibal, a mãe está ausente. Nenhum lugar para ela. Há mulheres, fêmeas - Freud emprega indiferentemente essas duas palavras. A pluralidade e o anonimato "definem" a vertente feminina, e o pai da horda não é daqueles que superestimam em larga medida a diferença 
entre uma mulher e uma mulher ${ }^{6}$. Seja em relação aos filhos, como ao pai, as fêmeas são o objeto de sua necessidade sexual: essa palavra evoca uma sexualidade mais instintual que pulsional, uma sexualidade préhumana.

Nada de mãe, nem tampouco de incesto. O único dos dois crimes edipianos cometidos na encenação freudiana das origens é o parricídio, de forma que os filhos assassinos não percorrem mais que a metade do caminho de Édipo ${ }^{7}$. Pode-se objetar: se o pai foi assassinado, mesmo assim é para que se apoderem das mulheres. Certamente, mas Freud toma todo o cuidado de precisar: desse ponto de vista, o crime não terá servido para nada.

$O$ ato homicida não podia satisfazer plenamente nenhum dos cúmplices. Era um ato, sob certos aspectos, inútil. Nenhum dos filhos podia realizar seu desejo primitivo de tomar o lugar do pai (T\&T, p. 164, n 1) [Note-se que o desejo primitivo $^{* * * *}$ não é exatamente o de possuir a mãe, mas de "tomar o lugar do pai"].

Esforçando-se em mostrar que, se existe uma vida psíquica em correspondência com a dos selvagens, seria ela menos a dos neuróticos que aquela dos psicanalistas, Lévi-Strauss escreve em A oleira ciumenta: "é Totem e tabu inteiro que, com um grande avanço, os Índios Jívaro viriam a antecipar no mito que lhes faz as vezes de Gênesis (...) a intriga do mito Jívaro aparece mesmo como mais rica e mais sutil" ${ }^{8}$. Mais sutil e mais rica? Sobretudo ela não tem grande coisa a ver com os ingredientes da narrativa freudiana. Levado por um humor crítico e condescendente, Lévi-Strauss comete um erro espantoso: o mito Jívaro começa por um incesto materno (a serpente Ahimbi deitou com sua mãe Mika, o pote). A

6 Cf. "palavra" de Bernard Shaw, citado por Freud em Psychologie des foules et analyse du moi, op. cit., p. 213.

7 Entre os filhos, o próprio Sigmund Freud. Sabe-se que ele viverá a redação de Totem e tabu como um acting out (passage à l'acte), o que explica, assim, a depressão que invadirá a obra acabada: "é algo de passar do desejo à sua realização" (comentário citado por E. Jones em The inception of Totem and tabou. In: Int. J. Psychoanal, 37 (1956), p. 35)

**** "Original" (ursprünglichen) seria mais justo e mais forte.

8 Paris, Plon, 1985, pp. 243-244. 
quem o marido-pai enganado ataca, então? A própria mãe, a quem ele acusa de ter favorecido o crime, "fazendo-a responsável (...) dos desejos incestuosos que ele mesmo experimentava a seu respeito". Só então sobreveio o primeiro homicídio, o dos filhos nascidos do incesto: a fim de vingarem a avó, decapitaram o esposo de sua mãe.

A mãe, o incesto estão no centro do mito Jívaro - uma e outro estão ausentes na teorização freudiana da origem da vida social, tal como apresenta o capítulo VI de Totem e tabu.

\section{A proibição do incesto}

No fundo dessa dupla ausência - tanto da figura materna quanto do crime incestuoso - qual pode ser, ainda, a significação da proibição do incesto? É preciso lembrar as palavras de Freud: de um menor valor que o interdito do parricídio, ela tem, primeiro, "um importante fundamento prático $^{* * * * *}$. A busca da satisfação das necessidades sexuais divide os homens, ameaça de ruína o estado social: a proibição do incesto se encarrega de pôr ordem nisso tudo, evitando, pois, que se reproduza a apropriação de todas as mulheres por um homem só.

Esta abordagem, mais antropológica que psicanalítica, não está somente na obra. Ela vem a Freud, retomada várias vezes, de forma a justificar o interdito por suas conseqüências - permitir o laço social, eludindo o que o precede - o desejo:

O horror que inspira o incesto (ato ímpio) repousa no fato de que, como conseqüência de uma vida sexual em comum (na época da Infância), os membros de uma família permanecem unidos e tornam-se incapazes de se ligar a estranhos ${ }^{9}$.

Passemos por cima da dificuldade lógica do argumento: é uma civilização já constituída que impõe a proibição, uma vez que, enquanto civilização, ela não saberia viver fora dessa última. Retenhamos simplesmente que o interdito do incesto, visto assim, refere-se a uma

\footnotetext{
***ssa fórmula é mais próxima do texto literal alemão do que aquela da tradução francesa - devo essa nota a François Robert.

$9 \quad$ S. Freud.. Manuscrit (31 mai 1897), In: La naissance de la psychanalyse (1969).
} 
exigência social, sem que seja necessário invocar impulsos afetivos. Freud reitera o mesmo raciocínio em Três ensaios sobre a sexualidade:

$O$ respeito à barreira contra o incesto é antes de tudo uma exigência cultural da sociedade, que deve sobretudo impedir que a família absorva os interesses que lhe são necessários para formar unidades sociais maiores ${ }^{10}$; ${ }^{\text {. }}$

Notemos, contudo, uma diferença sensível entre essas duas últimas citações e a tese defendida em Totem e tabu: dessa vez, é questão de uma "vida sexual em comum" ou de uma família muito absorvente... Em outros termos, de um tempo de promiscuidade original. Nada disso pode ser encontrado, no que concerne à narrativa que conduz da horda ao estado de sociedade - voltarei a isso - e não há nada antes da horda. Ponto de vista que Freud confirma explicitamente, na mesma época, em sua correspondência com Jung:

A promiscuidade original parece bastante improvável a muitos autores. Eu mesmo, com toda a modéstia, rendo homenagem a uma outra concepção dos tempos primitivos - a de Darwin ${ }^{11}$.

O que é feito, então, de um tempo original incestuoso? Inútil querer, à força, conciliar Freud consigo mesmo. A contradição tem os seus méritos; guardemo-nos, contudo, de solucionar os termos, para retomá-los depois.

Detenhamo-nos um pouco neste modo que tem Freud de fazer nascer o interdito do incesto dos imperativos da ligação social. Poder ligar-se uns aos outros (aos "estranhos") supõe que não se liga muito entre si. Quer dizer, não é "pelos" Jívaros que Freud está mais próximo

10 (1905), Paris, Gallimard, Idées, 1962, p. 136 (A passagem citada corresponde a uma tradução ligeiramente modificada, devido a J. Laplanche.

b N. do T.: ajuntamos aqui a tradução espanhola que Luis Lopez-Ballesteros faz desse trecho: "El respecto de estos límites es, ante todo, una exigencia civilizadora de la sociedad, que tiene que defenderse de la concentración, en la familia, de intereses que le son necesarios para la constitución de unidades sociales más elevadas(...)" S. Freud, Obras Completas, Trad. Luiz Lopez- Ballesteros, Espanha, Biblioteca Nueva, 1974, p. 1226.

11 Carta de 14-05-1912, In: Freud, Jung, Correspondance II (1975), p. 273. 
de Lévi-Strauss - cronologicamente, mas é preciso dizer, seguramente, o inverso. Sabe-se a insistência desse último em sublinhar que o interdito é sempre o inverso de uma prescrição positiva, de um convite à aliança. É de se ficar simplesmente surpreso com aquilo que, em Freud, precede semelhante teoria; em Moisés e a religião monoteísta, ocorre, como diz o autor, "O mandamento da exogamia, cuja expressão negativa é o incesto..."12. Esse reencontro, depois de tudo, não é tão surpreendente, uma vez que se sabe que Freud e Lévi-Strauss bebem, nessa circunstância, da mesma fonte: Tylor. Este último escrevia: "muitas vezes na historia, tribos selvagens devem ter tido claramente presente ao espírito a alternativa, simples e prática, entre se casar fora ou morrer fora (marrying out or dying out)"13.

A proximidade entre os pais fundadores - da psicanálise e da antropologia estrutural - vai mesmo mais longe: a mãe está tão ausente do livro de Lévi-Strauss ("eu não necessitava dessa hipótese"14) quanto está da tese freudiana, versão Totem e tabu. Convém, assim, sublinhar essa notável conjunção: "é em um mesmo movimento que a proibição do incesto é definida como uma exigência prática e que à mãe não é dado nenhum lugar”.

12 A frase completa de Freud é: "O mandamento da exogamia, cuja expressão negativa é o horror ao incesto, conformava-se à vontade do pai e prolongava essa vontade após sua expulsão" (L'homme Moïse et la religion monothéiste, 1939), Paris, Gallimard, nouvelle traduction, 1986, p.213. Lévi-Strauss provavelmente não seria a favor da segunda parte da frase. Questiona em que medida, contudo, "essa vontade do pai" está tão distante desta outra formulação do antropólogo: "é um fato universal que o laço de reciprocidade que funda o casamento não é estabelecido entre homens e mulheres, mas entre homens por meio das mulheres, que servem como principal pretexto", Les structures élémentaires de la parenté (1949), p. 149.

On a method of investigating the development of Institutions, applied to Laws of Marriage and Descent (1889). É verdade que é raro ver Lévi-Strauss ascender da proibição do incesto para além da aliança e da troca. Mas quando ele se interroga sobre "a explicação última", é aquela proposta por Tylor que lhe parece a mais provável (cf. La famille, 1979, p. 120).

A identidade. O seminário de C. Lévi-Strauss (1977), p. 100. Que a relação mãecriança seja não-qualificada deixa a psicanálise perplexa (cf. a discussão entre André Green e Claude Lévi-Strauss, nessa mesma obra). Mas os próprios antropólogos, quanto a isso, não encontraram, de forma alguma, a própria conclusão: cf. Adler e Cartry, "La transgression et sa dérision", In: L'homme, XI, 3, 1971. Eu mesmo tive a oportunidade, a respeito de sociedades afro-caribenhas, de insistir sobre a posição focal e estruturante do pólo materno (L'inceste focal dans la famille noir antillaise, 1987). 
É preciso insistir sobre o que há de surpreendente da parte de Freud ao sustentar semelhante posição. Dizer, da proibição do incesto, que ela responde ao cuidado de evitar a dissolução da comunidade, é situar o social ("a exigência cultural da sociedade") e não o psíquico, como fonte do interdito. Estamos longe do "horror", de onde nasce, contudo, Totem e tabu, longe da atração do incesto no filho (T\&T, p. 27), da perigosa virulência dos desejos incestuosos no primitivo (T\&T, p. 28), longe do que Freud afirma, além disso:

Não vemos qual necessidade haveria de defender o que ninguém deseja fazer e, em todos os casos, o que é defendido da maneira mais formal deve ser o objeto de um desejo (T\&T, p. 83-84).

Não há tabu que não deva a sua severidade a um desejo positivo. Essa realidade do desejo incestuoso- e o valor psíquico do interdito Freud a defende, na mesma época, contra os ataques de Jung. Que diz esse último?: "O senhor já se enganou uma vez com a sedução, o senhor irá recomeçar com o incesto”. Tudo é apenas fantasma, não realidade. Quanto ao interdito posto sobre o incesto materno, longe de nascer do desejo, ele tende, antes, a restituir valor ao que já não o tem ${ }^{15}$.

Contra Jung, Freud sustenta, ao mesmo tempo, tanto a força do desejo incestuoso, assim como a figura da mãe como objeto de desejo, e ainda a sexualidade como arque da vida psíquica, e tudo pontuado por uma "pílula amarga": “O senhor (Jung) me faz pensar em Adler, ou seja, em alguém que testemunha uma 'incompreensão total do inconsciente' "16. Como compreender, desde então, a depreciação da questão do incesto na tese final de Totem e tabu? É preciso, pois, ver aí uma simples questão de ponto de vista: fazendo-se antropólogo, Freud adotaria, por isso mesmo, os princípios ${ }^{\mathrm{c}}$ desse último - a prioridade do social sobre o psíquico. A conclusão, no entanto, seria precoce: conviria primeiro examinar a coerência interna da hipótese defendida, quero dizer a coerência psicanalítica, ou seja, a conjugação dos desejos positivos e

15 Jung, cartas de 27 de abril, de 08 e de 17 de maio de 1912, In: Freud, Jung, Correspondance II, op. cit., p. 270.

16 Freud, carta de 23 de maio de 1912, ibid., pp. 277-278.

c N. do T.: "les préalables" 
hostis, e perguntar, em função da configuração deduzida, qual pode ser aí, ainda, o lugar da mãe e do desejo.

\section{A mãe, apesar de tudo?}

A mãe é, pois, ausente, ou melhor, ela não é encontrável. Seríamos, então, tentados a dizer, como Freud, ao falar da mãe do filho do rei Lear, "ele devia, necessariamente, ter uma"17. Podemos visualizar nisso um pista?

Há ainda a alusão ao direito materno:

$E$, talvez, dessa situação [os tempos incertos que sucederam a morte do pai] que nasceu o direito materno descrito por Bachofen e que existiu até o dia em que foi substituído pela organização da família patriarcal (T\&T, p. 166)

De que direito se trata? Freud não o precisa; ele, no máximo, menciona a transmissão do totem em linha materna (T\&T, pp. 123, 163) sem explicar nem como e nem porque. É de se pensar nos sistemas matrilineares do parentesco, mas o que é, sobretudo, notável é que Freud evoca esse "tempo" para dele nada dizer. Temos, um pouco, o sentimento de uma concessão "de passagem" às teses etnológicas predominantes.

Freud fala um pouco mais disso quando escreve, na mesma época, a Jung:

O direito materno não deve ser confundido com o governo das mulheres. Poucas coisas falam a favor desse último. $O$ direito materno concorda particularmente bem com o aviltamento poligâmico da mulher ${ }^{18}$.

17 Carta a J. S. H. Branson, de 25 de março de 1934 (In: E. Jones, La vie e l'oeuvre de Sigmund Freud - III, 1969, p. 515. 
O direito materno não é o matriarcado; longe de significar elevação das mães, uma vez assassinado o pai, esse tempo intermediário corresponde a um rebaixamento suplementar das mulheres.

Os silêncios de Freud, seu embaraço em definir esse período de outra maneira que não em termos negativos, são inteiramente compreensíveis. De onde poderia nascer um tempo de direito materno, posto que a época precedente - da horda ao parricídio - não tem a mãe em consideração? Com efeito, é impossível deduzir da narrativa freudiana a matrilinearidade totêmica.

O embaraço de Freud se transforma então em perplexidade, quando evoca as divindades maternas:

Onde se encontra, nesta evolução, o lugar das divindades maternas, que talvez tenham precedido, em todos os cantos, os deuses-pai? Eu não saberia dizer (T\&T, p. 171).

Seria preciso primeiro uma mãe, para que se tivesse, em seguida, uma deusa-mãe: é bem aí que está o problema.

Freud sai, enfim, dessa indecisão quando fala acerca da agricultura - estamos historicamente já bem longe da horda:

Com a introdução da agricultura, a importância do filho na família patriarcal aumenta. Ele se entrega a novas manifestações de sua libido incestuosa, a qual encontra uma satisfação simbólica na cultura da terra, maternalmente nutritiva (T\&T, p. 175).

Eis, enfim, a mãe e os filhos e as "novas manifestações" de sua libido incestuosa; no entanto, seria mais exato falar de manifestações inteiramente novas. Freud retoma aqui uma argumentação já presente em Frazer. O inconveniente, contudo, é que faltam os elos que nos permitiriam compreender o surgimento desse período incestuoso tardio. Trata-se da agricultura, assim como das divindades e do direito materno, mas nada os religa à tese geral e tais coisas aparecem como que enquistadas em um desenvolvimento que nunca justifica a sua necessidade. 


\section{A mãe e o banquete}

Quando a mãe não é simplesmente ignorada, ela irrompe sem que seja possível integrar sua presença imprevista à lógica da argumentação. Mas há, talvez, que se coletar as raras referências do próprio Freud à dimensão materna: manifestamente ausente, a mãe não reaparece de forma sub-reptícia, apesar de Freud, isto é, contra a sua intenção explícita? Em qual momento? - Na hora do banquete, evidentemente.

Numerosos são os autores que, seguindo G. Róheim - mas poderse-ia encontrar os primeiros indicadores já em K. Abraham -, vão dedicar-se a deslocar do pai à mãe a etapa canibal da tese freudiana. Não que a mãe esteja presente nos lugares do festim - ela não participa, nada prepara -, mas é no nível da fantasmática, dos processos psíquicos em foco que tentaremos assinalar a pista. Propomo-nos a fazê-lo de dois modos, seja discutindo a natureza do objeto incorporado, seja deslocando o acento para o próprio processo de incorporação:

- Que deseja comer o pequeno Arpad, o "Chanteclair" de Ferenczi, que Freud torna um elo decisivo de sua própria argumentação? da "mãe confeito" (T\&T, 1912). Em sua "nova avaliação" de Totem e tabu, D. Freeman escreve, apoiando-se em T. W. M. Whiting: os desejos canibais são mais freqüentemente dirigidos à mãe que ao pai. $\mathrm{O}$ totemismo pode muito mais ser uma defesa fornecida contra os desejos canibais hostis do filho em direção à mãe do que contra a sua rivalidade edipiana com seu pai ${ }^{19}$.

Se o objeto "canibalizado" é, no fundo, a mãe, a hipótese freudiana seria, então, um logro, uma representação deslocada de um tempo mais arcaico. A respeito Anzieu formula claramente: "o mito freudiano é uma estruturação efetuada posteriormentee, quando da fase edipiana, de um fantasma oral" ${ }^{20}$.

- O banquete canibal totêmico, tal como Freud o entende, é inseparável da identificação (ao pai) - comer não é somente destruir, é também fazer seu. Ora, pouco tempo depois de Totem e tabu, em 1915, o próprio Freud anotará que o "protótipo do que será mais tarde a

19 "Totem e tabu, une nouvelle évaluation", In: L'anthropologie psychanalytique depuis totem et tabou, sob a direção de W. Muensterberger, Paris, Payot, 1976, p. 65, n. 30.

20 "La fantasmatique oral dans le group", In: Nouvelle revue de psychanalyse, 1972, n. 6, p. 37. 
identificação"21 é constituído pela incorporação do objeto, característica da organização sexual oral-canibal, pré-edipiana, pois. Desde então, torna-se inútil censurar Freud pelo seu erro (quando se come, come-se sempre a mãe e não o pai); o processo de incorporação, por si só, leva o selo da relação com a mãe oral, mesmo se o objeto incorporado é conotado como paternal. J. Laplanche anota: "Banquete totêmico ou comunhão, a identificação secundária e, desta vez, identificação ao homem - é marcada, em seu próprio processo, de identificação primária, pela identificação ao seio materno"22. O banquete canibal condensaria em um mesmo gesto as relações identificatórias dos filhos com o pai e com a mãe.

Mais um passo, identificações em direção aos desejos primitivos. A. Green escreve: "Se o motivo do parricídio reside naquilo que cria o privilégio maior do pai, o gozo da mãe, pode-se pensar que essa transgressão é dupla, a incorporação, que segue o homicídio, do poder e, indiretamente, esse gozo "23. O pai é destruído, o incesto materno é consumidof. Aos duplos bocadosg, em suma, o ato canibal reabsorveria, em si mesmo, os dois crimes edipianos.

É perfeitamente legítimo, de um ponto de vista analítico - não falemos da multiplicidade de objeções etnológicas, genéticas, zoológicas... que se pode fazer a Totem e tabu - julgar insatisfatória a argumentação de Freud; notadamente a maneira com que ela se esgota no confronto com o pai e com os irmãos. Procuraremos, seja reintroduzir a figura materna, excessivamente ausente, aproveitando-nos de algumas aberturas deixadas pelo enunciado da tese (a oralidade do banquete), seja reescrever a própria narrativa, ajuntando-lhe alguns ingredientes. O trabalho de Géza Róheim é um belo exemplo dessa última maneira de ver: há dois atores no drama edipiano, escreve ele, e não basta. Ao pai originário, à horda de irmãos, é preciso ajuntar os filhos - e suas mães. Filhos, espectadores aterrorizados pela intensidade dos confrontos, traumatizados pelo mais violento deles, aquele do pai e da mãe na cena primitiva. O complexo paterno cede ao mais arcaico dos fantasmas. Fantasma primeiro, do qual a cultura se protege, ao mesmo tempo que o repete e o sublima. O próprio totemismo (Róheim se refere à Austrália

\footnotetext{
21 Trois essais..., op. cit., p. 95.

22 Problematiques I, L'angoisse, Paris (1980), p. 320.

23 "Le cannibalisme: realité ou fantasme agi?", In: N. R. P., n. 6, op. cit., p. 37.
} 
central) tem um precursor nas crenças em demônios, que são projeções dos pais unidos no coito. O culto totêmico não é mais que uma segunda tentativa de assenhorar-se dessas impressões ${ }^{24}$.

Meu objetivo não é de passar em revista essas diferentes versões, de avaliá-las, ou seja, de adicionar-lhes mais uma; menos ainda de colocar a tese freudiana ao abrigo de seus detratores. A questão que me proponho seria antes esta: ao querer-se atenuar as "carências" de Totem e tabu, não se formula uma (ou mais) interpretação que, menos que completar a teoria freudiana, impede-nos de ver as suas implicações últimas? Antes de concluir pela falta, pela ausência (da mãe), é preciso preliminarmente, ainda, ter levado a tese aos seus últimos limites ${ }^{\mathrm{d}}$, às suas últimas conseqüências. Meu ponto de vista é de que nada falta à hipótese de Freud - o que não prejulga a sua verdade, isto é, a sua pretensão de dar conta da origem do laço social: a coerência interna de uma teoria não é garantia de sua pertinência.

Resta demonstrar essa completude.

\section{O amor entre homens}

Na exposição final de Totem e tabu, o único parentesco existente é o masculino: entre pai e filho, entre irmãos. Se não há "mãe" - ausente do "sistema de denominações", poder-se-ia dizer -, é porque faltam as relações de objeto, de investimentos, suscetíveis de lhe dar corpo. Não há, com efeito, nada a esperar, desse ponto de vista, do pai da horda, o que Freud mais tarde tornará mais preciso: "seu eu tinha poucos laços libidinosos, ele não amava ninguém a não ser a si mesmo, e amava os outros somente na medida em que serviam às suas necessidades" ${ }^{25}$. Quanto aos filhos, nada a considerar: quanto ao seu amor, ao seu desejo, estavam fora de cogitação. Tratava-se somente das "necessidades", das "exigências" do primeiroj. Posto que os filhos, pelo viés das mulheres, tenham apenas necessidades insatisfeitas, isso os dispensa de estabelecer relações com elas.

O único parentesco, mas também o único laço libidinal é entre o pai e os filhos - mais tarde entre irmãos, igualmente. Um laço de ódio, certamente, mas não unicamente; sabe-se da insistência de Freud sobre a

\footnotetext{
24 L'énigme du Sphinx (1976), p. 275-277.

d N. do T.: "retranchements"

25 "Psychologie des foules...", op. cit., p. 191.
} 
ambivalência. Em relação ao pai, o respeito rivaliza-se ao medo, "odiando-o, [os filhos] o amam e o admiram" (T\&T, p. 164). O pequeno Hans que, com seu "primo" Arpad, lança um "raio de luz" à interpretação freudiana, só pode identificar-se com o pai-cavalo quando o medo já esta apaziguado (T\&T, p. 150). A identificação, passagem do ter ao ser, põese no lugar da escolha do objeto, apóia-se mais no amor do que na rivalidade.

A refeição canibal, vetor da identificação, carrega, ela mesma, as marcas da ambivalência: devorar o pai é destruí-lo, mas também fazê-lo seu. Assim, da frase de A. Green, citada acima, sobressai que comer é ao mesmo tempo consumar o assassínio (do pai) e o incesto (com a mãe). Os etnólogos têm fartamente estabelecido a equivalência entre os interditos alimentares e os interditos sexuais ${ }^{26}$, e a consumação do totem eqüivale a um incesto, escreve M. Augé ${ }^{27}$. Porém, se o banquete dos irmãos, em Totem e tabu, é bem um incesto alimentar, não é preciso apressar-se em deduzi-lo: comer o pai é gozar da mãe - mais uma vez, ainda, a mulher não é constituída como tal. Comer o pai é, antes de tudo, penetrar-se dele .

A equação encontrada entre a oralidade do banquete e a fantasmática materna é, entretanto, um recurso que mascara as conotações anais e genitais do festim ${ }^{28}$. O que se come, de preferência, no decurso do banquete comemorativo? Que partes do animal são incorporadas, para tornar-se igual ao pai (T\&T, p. 170)? Apropriar-se do falo paterno, dele penetrar-se... A equivalência boca-ânus, de um lado, e o pedaço genital, de outro, adicionam uma espessura fantasmática à qual a redução à oralidade interpõe uma cortina de fumaça.

O incesto alimentar em Totem e Tabu é homossexual. Pode-se dizer dos filhos da horda o que Freud escreve, em outro lugar, do canibal: "ele ama os seus inimigos a ponto de devorá-los e ele não devora aquilo que ele não pode, de uma forma ou de outra, amar". ${ }^{29}$

26 Cf. L \& R. Makarius, "Prohibition de l'inceste et interdits alimentaires", In: Diogène, 1960, n. 30 .

27 "Les métamorphoses du vampire", In: N. R. P., n. 6, op. cit., p. 140.

e N. do T.: "Manger le père c'est d'abord s'en pénetrer"

28 Sur les fantasmes oraux cannibaliques comme des fantasmes-écrans, cf. P. Fédida, "Le cannibal mélancolique" In: N.R.P., n 6, op. cit., p. 127.

29 "Psychologie des foules"..., op. cit., p. 168. Tão logo foi estabelecida a correlação entre destruir o pai e desfrutar a mãe ( $c f$. supra), A. Green matiza a sua interpretação, 
O que se torna, então, um pouco mais clara, é a homossexualidade característica da horda fraterna, uma homossexualidade que Freud parece, a princípio, apresentar como resultado da penúria, do exílio - falta de melhor, falta de mulheresl - mas que, é preciso notar, é mantida para além do homicídio:

Eles [os irmãos] salvaram a organização que os havia tornado fortes e que repousava, talvez, sobre os sentimentos e as práticas homossexuais, que se instalavam entre eles na época de seu exílio (T\&T, p. 165-166).

A idéia de uma cumplicidade do amor homossexual (masculino) e do laço social ("fato notável, cuja explicação não deixaria de nos levar longe" ${ }^{130}$ ), Freud a aponta muitas vezes. Para tal homossexualidade, uma única gênese é possível: um tal amor pelo pai, em que se misturam o medo e a admiração, antes de se transformar em "ideal de submissão", através do qual é mantida a "nostalgia". Do amor dirigido ao pai, então, do apego entre si: é por um mesmo movimento que são elaborados a homossexualidade fraterna e o estado de sociedade.

À vista dessa homossexualidade, as "necessidades" sexuais dos filhos se revestem de outra significação. Não é a mãe quem é exigida, mas as-mulheres-do-pai. Se cada um quer "tê-las todas para si", é a "exemplo do pai" ( T\&T, p. 165). Às custas das mulheres desenrola-se, assim, o amor entre os homens. Talvez estejamos aqui atingindo o próprio princípio da aliança, base mínima do laço social: reinterpretando a afirmação de Lévi-Strauss, "são os homens que permutam as mulheres", G. Devereaux escreve: há uma estreita relação "entre a permuta de mulheres e as pulsões homossexuais latentes dos homens que as intercambiam" ${ }^{31}$.

não para substituir o incesto materno pelo incesto homossexual, mas para sublinhar que o primeiro fracassa. Posto que o banquete é coletivo, já social, é introjetado somente o poder proibitivo do pai e não sua potência/gozo (puissance/jouissance) (In: N.R.P., n 6, op. cit., p. 37).

"Psychologie des foules...", op. cit., p. 214-215.

31 Considérations ethnopsychanalytiques sur la notion de parenté. In: Ethnopsychanalyse complémentariste (1972). 


\section{A mãe, a fêmea}

É talvez agora, uma vez percorridas as vertentes opostas da relação entre pais e filhos, que podemos encontrar a mãe em Totem $e$ tabu. Sendo mulher ou fêmea, ela não escapa à apropriação ${ }^{f}$ do pai senão para cair sob o "envilecimento poligâmico", e em seqüência ao homicídio $^{32}$. Uma mãe sexuada, envilecida... A outra, a mãe do amor materno, não é ausente nem descartada. Freud a reencontra através da hipótese de Atkinson (Primal Law, 1903):

Atkinson, a quem os dados da psicanálise não eram familiares e que não conhecia os estudos de Robertson Smith, encontra uma fase de transição menos violenta [que a devoração do pai] entre a horda primitiva e o estado social seguinte, representado por uma comunidade na qual um grande número de homens vive pacificamente. Seria, segundo ele, o amor materno que teria conseguido que os filhos mais jovens, primeiramente, e os outros, em seguida, ficassem na horda, onde eles não eram, aliás, tolerados, senão reconhecendo o privilégio sexual do pai, renunciando a toda a cobiça em relação à mãe e às irmãs (T\&T, p. 164, nota 2 - grifos meus).

O erro de Atkinson: ter introduzido o amor materno em vez e no lugar da mediação canibal ${ }^{33}$. As razões desse erro: ignorância das teses de Robertson Smith e desconhecimento da psicanálise. A família

f N. do T.: "elle n'échappe à la main basse du père que pour tomber dans l'“avilissement polygamique”"

32 É impossível, para justificar esses termos, ("fêmea", "envilecimento"), apelar ao primitivismo: os propósitos de Freud explicar-se-iam pelo lado "primata", "hominídeo" dos seres invocados. Mais uma vez, estamos em um espaço de parentesco constituído e de um parentesco social, se o há: há pais e filhos. Certamente Freud, aqui, remonta até ao longínquo da origem da humanidade, mas, como já foi sublinhado, quando ele reflete os fenômenos sociais contemporâneos, é para notar a continuidade essencial entre a horda (e seu tirano) e a multidão (e seu condutor).

33 Os partidários da introdução da mãe na hora do banquete encontrarão aí um argumento suplementar, com a condição de ir além do dito por Freud e de introduzir o que ele deliberadamente descarta. 
ciclopeana de Atkinson é certamente uma "notável teoria", concordante nos "pontos essenciais" com aquela que nós, segundo Freud, preconizamos, mas "vemos também os pontos sobre os quais ela daí se separa" (T\&T, p. 164, n. 2).

E, entretanto, de um ponto de vista analítico, não falta consistência à idéia de "mãe amante", de Atkinson. Porta-voz e cúmplice dos filhos mais jovens, ela troca essa terna cumplicidade pelo silêncio imposto à "cobiça". Mas Freud não a retém. Fica apenas a mãe trivial, a fêmea. Os filhos de Totem e tabu são filhos de um pai admirado - antes que o ódio o abata - e de uma fêmea; escrevendo seu romance da cultura, Freud reata com uma das vertentes do romance familiar - o rei e a puta.

Se, para além do sistema totêmico, é o estado de sociedade que nasce das "condições do complexo de Édipo", convém precisar: é da forma negativa/invertida do complexo. Entendendo-a assim, nada falta à tese freudiana, nenhuma carência. Podemos apenas ater-nos ao "complexo paterno", e a mãe está aí, aviltada, fêmea desprezada3434. O ódio às mulheres, de um lado, e o respeito e a admiração pelo pai, de outro: o laço social tece-se na homossexualidade e não tem a sua durabilidade senão pelo afastamento do feminino.

Sem querer colocar a teoria freudiana à prova das sociedades reais, notemos, no entanto, que não falta coerência à hipótese; não é do estado de sociedade conhecido, passado ou presente, que se empurra às fronteiras o feminino, a sexualidade feminina: potências noturnas da floresta, feiticeiras cúmplices das forças diabólicas ou, simplesmente, penates confinados ao espaço doméstico3535.

Nada de mais normal, afinal de contas, que na origem do laço social encontremos a forma negativa do complexo de Édipo. J.

34 Na forma positiva do complexo, o pai é um rival para os filhos. Na forma negativa, a mãe é mais desprezada do que rival: sem duvida, é preciso ver aí o inverso dos processos de idealização, que se misturam sempre ao amor dos filhos pelo pai.

35 Em que medida as sociedades ocidentais contemporâneas, através do que elas deixam filtrar do desejo feminino na emancipação das mulheres, rompem com um silêncio milenar? Antes de tudo, esse silêncio nunca foi absoluto e poder-se-ia fazer um inventário daqueles momentos históricos mais permeáveis ao que desejam as mulheres. Seja como for, uma das respostas masculinas de hoje testemunha que isso não ocorre sem problemas: a pornografia. Lugar de reasseguramento viril, em que o homem restabelece a mulher como objeto manipulável; lugar tranqüilo, enfim dentro de uma economia totalmente masturbatória, desembaraçada do desejo feminino, isto é, da própria sexualidade. 
Laplanche escreve: "a identificação normatizante (no sentido em que Freud emprega o termo "normal": de acordo com o sexo biológico e socialmente considerada normal) tem como motor a escolha de objeto homossexual" ${ }^{\text {"36 }}$. A qualidade da identificação, vetor do processo de socialização, depende da intensidade da escolha do objeto preexistente: a identificação ulterior do filho ao pai nasce do amor prévio ${ }^{37}$.

\section{O amor desiludido}

Um pai temido, mas profundamente respeitado, admirado, tão logo deificado... Falta algo à nossa análise: por que matar o pai tão amado? Pode-se objetar à nossa argumentação que o parricídio é central em Totem e tabu; o crime visa apoderar-se das mulheres, inscrevendo-se, pois, manifestamente, na dinâmica do Édipo positivo...

Isso é negligenciar todas as razões, do homicídio, que possam surgir em uma outra vertente. O pai provoca a admiração, seduz por sua potência, obrigando a que a ele se esteja apegado, mas não responde à demanda de amor que, entretanto, ele mesmo induz. Ele não divide nada, basta-lhe ser amado sem nada dar em troca. Ele tem a natureza dos chefes absolutamente narcísicos ${ }^{38}$.

O assassínio do pai é o gesto do amor desiludido. É preciso a isso adicionar uma condição necessária: se o ódio aos irmãos abate-se sobre o amor dos filhos, é que eles "transpuseram o espaço que vai da identificação mútua ao amor objetal homossexual", adquirindo, assim, $a$ liberdade de matar o objeto destronado ${ }^{39}$.

Esse retorno do amor como ódio, via decepção, joga uma nova luz sobre o banquete canibal. Esse último conjuga, à forma ativa, os três termos: os filhos/comer/o pai. Mas, quando Freud reencontra na clínica esse fantasma de devoração (do pequeno Hans, do Homem dos Lobos), é, sob a forma passiva, ser comido pelo pai: "... a representação da devoração dos filhos pelo pai é a expressão deteriorada, através de regressão, de uma moção terna passiva, que representa o desejo de ser

\footnotetext{
36 Problématiques I, op. cit., p. 345.

37 Cf. S. Freud, "Psychologie des foules...", op. cit., p. 206.

38 Ibid., p. 191.

39 Ibid., p. 192.
} 
amado pelo pai como objeto, no sentido do erotismo genital"40. Como o amor retorna na forma de ódio, a cena das origens inverte o fantasma "originário": não ser comido-amado pelo pai, mas devorar o pai odiado. O caminho dos irmãos em Totem e tabu pode, assim, ser descrito como uma réplica ao que resiste ao cumprimento do desejo, ao que se opõe ao fantasma; uma formação reativa ao amor desiludido.

\section{II - A MÃE E O FILHO MAIS NOVO}

Muitas vezes Freud retorna a essa sua narrativa da horda originária, não simplesmente para repeti-la, mas introduz novas variantes $^{41}$. Essas variantes concernem a um ponto de vista bem preciso: a questão materna. Em seu interior, é preciso distinguir dois aspectos:

- o lugar designado ao amor materno (e, como conseqüência, ao filho mais novo), e

- a descrição do segundo período, o tempo pós-morte (pós-horda), uma vez morto/assimilado o pai.

Os principais textos de referência são aqui Psicologia de massas e análise do eu (1921) e Moisés e o monoteísmo (1939). A eles é preciso, ainda, ajuntar o manuscrito de Freud recentemente encontrado e publicado sob o titulo Visão geral das neuroses de transferência ${ }^{g}$ (1915).

O amor materno. Ele ocupa, já foi dito, uma posição mediadora na tese de Atkinson: é graças a esse amor que cessam as encarnecidas lutas, nas quais se confrontam os filhos já vitoriosos. Essa outra versão dos primeiros tempos, Freud não a descobre senão no fim da vida; ele a evoca em Totem e tabu, mas é para afastá-la, preferindo uma transição mais "violenta", o banquete canibal. A narrativa de Freud parece mais bárbara, mais primitiva, excluindo, sobretudo, a intervenção materna, correlativa ao incesto.

40 S. Freud. Inhibition, symptôme et angoisse (1951[1926]), pp. 23-24. Também L'homme aux loups (1918), onde Freud evoca as conotações ano-genitais, às quais já fizemos referência, a propósito do momento de devoração: ter medo de ser comido pelo lobo-pai procede do "medo do pai no coito".

41 Salvo em Selbst Dartellung - die Frage der Lienanalyse (1925), onde a tese de Totem e tabu é simplesmente resumida.

g N. do T.: "Vue d'ensemble des névroses de transfert", no texto. 
Freud irá reter, pois, entre as variantes, o que não encontrava lugar na tese inicial, mas com uma modificação importante em relação à argumentação de Atkinson: o amor materno está presente, certamente, mas, ao invés de suceder ao assassinato, ele o precede. Freud ajunta uma peça suplementar à vida da horda, sem renunciar ao que, a seus olhos, permanece essencial: nada de trocar o banquete canibal pelo amor materno. Esse último não intervém em substituição, mas em complemento:

Por razões naturais, existia [no seio da horda] uma situação privilegiada em favor dos filhos mais novos [os mais velhos "ou eram abatidos ou eram castrados ou eram banidos"], que, protegidos pelo amor das mães, podiam tirar vantagem do envelhecimento do pai $e$ substituí-lo após a sua morte ${ }^{42}$.

Segue a narrativa da "etapa decisiva": a associação dos irmãos perseguidos, a vitória sobre o pai e a sua cruenta devoração ${ }^{\mathrm{h}} \mathrm{O}$ manuscrito de 1915 diz a mesma coisa, com alguns detalhes suplementares:

o filho mais novo tinha uma oportunidade de escapar ao destino dos mais velhos "e de tornar-se o sucessor do pai, graças à intercessão da mãe, mas sobretudo pelo envelhecimento do pai e sua necessidade de ajuda"43.

A nova versão introduz a mãe, excluída de Totem e tabu, o que, assim, parece atenuar a incompletude da primeira tese. Olhando um pouco mais de perto, contudo, é a coerência da argumentação que se encontra atingida: temos agora um filho posto ao abrigo do ciúme do pai por meio da ternura materna, um filho que ocupa o lugar do pai, no momento oportuno, isto é, sobrevinda a sua morte. O próprio pai já não se assemelha ao tirano castrador de Totem e tabu, o qual era "preciso

\footnotetext{
S. Freud. L'homme Moïse et la religion monothéiste (1986[1939]), p. 171

h N. do T.: "sa dévoration crue"

43 S. Freud. Vue d'ensemble des névroses de transfert (1986), p. 40. N. do t: Traduzido para o português como Neuroses de transferência; uma síntese (manuscrito recémdescoberto (1987).
} 
derrubar": este não é mais que um velho senil, reduzido a pedir ajuda; a quem, senão à mãe? O poder mudou de mão. Assim, para que matar, para que devorar esse moribundo que já cedeu seu lugar? - O parricídio é inútil. Se um grupo social sabe esperar a velhice, a morte do patriarca, não é mais necessário eliminá-lo.

Assim repensada, a vida da horda evoca um estado social acabado. Pode-se objetá-lo através da existência do grupo de filhos perseguidos, privados de mulheres; é provável, de fato, que uma ou outra sociedade real já tenha elaborado algum modelo aproximado de uma discriminação semelhante: imaginemos o destino dos caçulas no Japão tradicional ou o caso dos jovens Tiwi, obrigados a esperar até os trinta anos para possuir uma mulher, ou várias ${ }^{44}$.

\section{Duas teorias}

Não há, pois, em Freud, uma teoria da origem do laço social, mas duas. As variantes não são "remanejamentos" da tese inicial, formulada em Totem e tabu, mas elas delineiam uma outra socialidade. O primeiro cenário, entre pai e os filhos mais velhos, leva à ordem patriarcal. O segundo, entre a mãe e os filhos mais jovens, prepara o "reino das mulheres".

A sociedade patriarcal e o reino das mulheres não são dois momentos sucessivos de uma mesma evolução; o primeiro não leva a outro, nem o inverso. As duas ordens se excluem, seu antagonismo não é dialético: o império de uma é a morte de outra, ou, ao menos, seu silêncio.

A primeira teoria, que ocupa em Freud um lugar proeminente, associa um pai admirado-odiado-assassinado/assimilado-deificado e irmãos logo ligados entre si, após terem estado apegados ao pai e, depois, expulsos por ele. Da atitude passiva e admiradora do primeiro momento até os sentimentos mútuos no interior da horda fraterna, o amor homossexual preside o nascimento e o estabelecimento do estado de sociedade. Quanto às mulheres, elas nem mesmo têm acesso ao mínimo social do parentesco: elas permanecem mulheres (fêmeas), botim do pai, ou soçobram no "envilecimento poligâmico", após a sua morte.

Podemos dizer que essa apresentação é excessivamente restritiva, e busca reconciliar Freud consigo mesmo - a primeira versão com as

44 Cf. C.W.M. Hart \& R. R. Pilling, The Tiwi of North Australia (1964). 
variantes ulteriores: os irmãos de Totem e tabu são adolescentes, ou seja, homens jovens. Evocando o mais novo (e sua mãe), Freud não descreverá somente uma idade precoce, negligenciada pelas primeiras formulações.

Notemos isso: ao ser introduzido o par mãe/filho mais jovem, não é somente o pai que dele é descartado (velho, suplicando por ajuda, tão logo morto, sem ter sido assassinado), mas também os irmãos mais velhos, os "adolescentes" que vêem o poder escapar "sob o seu nariz" em direção ao eleito do desejo materno; o pai tornado escárnio e o direito de primogenitura ridicularizado. Impossível, então, manter juntos, em uma figura de reconciliação, as duas gêneses do laço social: o jogo se dá ou entre o pai e os mais velhos ou entre a mãe e o mais jovem.

O destino dado à questão do incesto em Totem e tabu (do horror a uma proibição prática) significa que o estado social patriarcal não pode nascer senão do silêncio completo, imposto ao desejo incestuoso, e do descarte do feminino. O incesto é inter-dito, a fim de evitar a divisão, mas o desejo incestuoso desaparece como questão.

Enquanto Freud se atém à linha patriarcal de sua interpretação, as referências à dimensão materna (direito e divindades) ficam marcadas pelo selo da incerteza, ou seja, da mais total perplexidade. Se ele se esforça em ser mais preciso, não é, de forma alguma, para dar às mães algum lugar, mas antes para afastá-las mais. Ele escreve, então, a Jung, dizendo que o direito materno não é certamente o "governo das mulheres": isso seria exatamente o contrário, a sua submissão agravada, o tempo do "envilecimento".

A aparição da mãe e do filho mais jovem não somente desloca as relações de poder no seio da horda originária, mas ainda subverte a concepção dos tempos que se seguem à morte do patriarca:

Uma boa parte do poder absoluto liberado pela expulsão do pai passou às mulheres, o que significou a vinda do tempo do matriarcado ${ }^{45}$.

Uma vez "fraturado o poder paterno", instaura-se o "reino das mulheres". Freud afirma aí exatamente o contrário do que sustentava em 1912, ao escrever Totem e tabu. Na primeira teoria, posto que a mãe é

45 L'homme Moïse..., op. cit., p. 172 e p. 236. (Cf. igualmente em "Psychologie des foules", op. cit., p. 207). 
ausente no tempo da horda (ou melhor, ausentada), Freud nada pode dizer do direito materno, suposto como a etapa seguinte. Não pode dizer que a mãe e o filho caçula, ao contrário, se apropriam do poder mesmo antes que o velho tenha expirado, e que é muito "natural" que o tempo pós-horda consagre os privilégios maternos.

A primeira hipótese leva, pois, à ordem social patriarcal, e a segunda a uma sociedade de regência. A história da França, que não concede o poder a uma mulher a não ser que, para tanto, o rei seja uma criança, talvez desse alguns exemplos dessa última organização. Os trinta anos do reinado de Catarina de Médicis, em lugar dos filhos interpostos (Francisco II, Carlos IX e Henrique III), mereceria, desse ponto de vista, uma atenção particular.

A segunda teoria modifica radicalmente o sentido do direito materno, fazendo, também, desaparecer a perplexidade em relação às divindades maternas. Essas últimas surgem sem razão na tese inicial, sem que as razões sejam fornecidas pela argumentação. Introduzada a mãe e o filho caçula, o poder das regentes, e a questão resolve-se por si mesma: uma vez posto fim ao "reino das mulheres", as divindades maternas surgem como reparação desse tempo abolido.

As deusas-mãe nasceram provavelmente [isto não é mais "eu não saberia dizê-lo", é tão afirmativo que permite-lhe o distanciamento das origens] na época do matriarcado como compensação às mães postas em segundo plano ${ }^{46}$.

\section{Radicalmente eliminado}

De certo modo, a segunda teoria parece mais "suave", mais elaborada que a primeira. O pai, antes que assassinado, envelhece; a mediação materna permite ao filho não ser expulso/castrado (chassé/châtré); ela porta a palavra do pai junto ao filho e impõe silêncio à cobiça. Não é mais a arcaica mulher-fêmea, mas a mãe terna.

$\mathrm{E}$, contudo, há nesse trio (um moribundo que suplica por ajuda, uma mãe e seu filho, cúmplices, espreitando a morte do velho homem) algo de temeroso, que pressagia a natureza da etapa seguinte: o reino das mulheres. Mesmo quando já não nega a existência de tal período, Freud

46 Ibid., p. 174 (igualmente em "Psychologie des foules...", op. cit., p. 207). 
diz pouco sobre ele, mas esse pouco tem ainda os acentos de um perigo que é preciso conjurar, de uma ordem imprevisível que é preciso quebrar:

o homem tornou-se chefe de família e cassou os privilégios desse reino das mulheres, instaurado durante o período sem pai ${ }^{47}$.

Outro sinal do perigo a que esse período materno expõe o nascente estado de sociedade: sua brevidade, sua eliminação rápida e melhor - sua erradicação sem retorno possível:

Esse privilégio do mais jovem foi radicalmente eliminado da organização social que se seguiu e foi substituído pelo direito de primogenitura ${ }^{48}$.

Fica, contudo, alguma coisa desse reino efêmero: as lendas guardam algo de sua lembrança ("podemos facilmente reconhecer seus traços no mito e no conto"49). A isso poderíamos ajuntar as divindades reparatórias.

Há, parece-me, uma só forma de compreender essa eliminação radical de um tempo que não teria durado muito: qual seria o privilégio a ser tão impacientemente derrubado? O laço incestuoso do filho mais jovem à mãe. O que importa fazer desaparecer - e rápido - é uma (des)ordem social cuja matriz é o desejo incestuoso.

Eis, pois, uma época que ficaria sem futuro ${ }^{50} \ldots$ mas, talvez, sem precursor: há o primeiro homem, aquele anterior às glaciações, quando então a terra estava quente e profusa:

\footnotetext{
47 "Psychologie des foules...", op. cit., p. 207.

Vue d'ensemble des névroses de transfert, op. cit., p. 40. Grifos meus.

Ibid.

50 É, freqüentemente, um ponto de vista inverso o que se tem hoje na literatura psicanalítica. S. Leclaire evoca uma "ordem-social-incestocrática" (Rompre les charmes (1981), p. 252); F. Roustang, quanto a isso, se pergunta: como escapar ao Um, "como é possível que haja ainda a separação?" ("Le mythe de l'Un", In: Confrontation, Le lien social (1981), p. 12). Entre Freud e esses autores houve Lacan, que afirmava que "a ordem da família humana tem os fundamentos subtraídos à força do macho". Exit a horda primitiva, no principio era o matriarcado (Les complexes familiaux, 1984, pp. 54-55).
} 
o animal humano passou a sua existência em um meio de extrema abundância e capaz de satisfazer todas as suas necessidades, da qual conservamos o eco no mito do paraíso perdido ${ }^{51}$.

Talvez a "eliminação radical" do período do direito materno torne-se um pouco mais compreensível: seria preciso duas cenas (pré)históricas - nas quais a tentação incestuosa reencontra o objeto de seu desejo - para engendrar o traumatismo e suas conseqüências: o recalcamento, a eliminação sem retorno daquilo que ameaça o equilíbrio social. Cronologicamente ulterior à horda, o reino das mulheres ser-lhe-á "arcaicamente" anterior, fazendo reviver o calor paradisíaco e deletério da alvorada dos tempos.

Como compreender, agora, a transição - essa palavra é muito suave para o que deve ser derrubado - do reino das mulheres para a ordem patriarcal restabelecida? Totem e tabu nada diz e tem o seu motivo: o momento patriarcal não encontra aí qualquer lugar. As variantes não são nada explícitas. É em Psicologia de massas e análise do eu, mas quando Freud evoca o quadro familiar, social, e não o mundo primitivo da horda, que podemos colher algumas indicações:

O mais velho dos filhos quereria, é certo, ciumentamente rechaçar aquele que viria logo em seguida, mantê-lo afastado dos pais e despojá-lo de seus direitos, mas, em presença do fato de que esse filho é também - como todos os outros que viriam - amado por seus pais do mesmo modo, e em conseqüência da impossibilidade de perseverar em sua atitude hostil sem prejuízo pessoal, ele é, então, forçado à identificação com os outros filhos; forma-se, assim, no grupo de filhos um sentimento de massa ou de comunidade, o qual mais tarde, na escola, continuará o seu desenvolvimento. A primeira exigência dessa formação reativa é aquela de justiça, de tratamento igual para todos (...) Se não se pode ser o privilegiado, que, ao menos, nenhum dos outros o seja (...) O sentimento social repousa, assim, sobre o retorno de um sentimento a principio hostil, sobre um laço, com 
um caracter positivo, da natureza de uma identificação. De acordo com o que até agora podemos compreender do desenrolar das coisas, esse retorno parece cumprir-se sob a influência de um laço coletivo de ternura com uma pessoa situada fora da multidão ${ }^{52}$.

Se destacamos esse episódio do ciúme fraterno e o colocamos contra o fundo da narração das origens, tem-se: no tempo do reino das mulheres, o objeto do ódio do grupo de irmãos mais velhos desprezados não é mais o pai da horda, mas o mais jovem dos filhos, o mais amado, $o$ privilegiado (a própria mãe é poupada, como se o desejo incestuoso não lhe dissesse também respeito). $\mathrm{O}$ ódio contra o mais jovem e a impaciência em abolir o privilégio não bastam, contudo, para que nasça uma formação social outra; é preciso o laço de amor: não o amor da mãe, excessivamente singular, excessivamente exclusivo ${ }^{53}$, mas o amor homossexual dirigido ao pai, à "pessoa situada fora da multidão", que, desse modo, reúne o grupo de irmãos mais velhos.

Mais que o ódio dos mais velhos, entretanto, ou mais que qualquer outro fator histórico, o que abole o privilégio incestuoso é a "decisão" de Freud de fazer voltar o pai. W Granoff insistiu fortemente acerca desse momento da teorização, acerca do perigo que ele se esforça em conjurar: "após o afastamento do pai o descanso é de curta duração. A situação é pior, então, face à imagem feminina, tornada única senhora do terreno" 54 .

A célebre frase de Moisés e a religião monoteísta mostra claramente o sentido dessa decisão:

a passagem da mãe ao pai caracteriza (...) uma vitória da vida do espírito sobre a vida sensorial; dessa forma, é um progresso da civilização, pois a maternidade é atestada pelo testemunho dos sentidos, enquanto a

\footnotetext{
52 "Psychologie des foules...", op. cit., p. 186, 187-188.

53 Outro deslocamento sensível de Atkinson a Freud: o primeiro fala dos filhos mais jovens e o segundo fala do filho mais jovem.

54 Filiations (1975), p. 540.
} 
paternidade é uma conjectura, é ela edificada sobre uma dedução e sobre um postulado ${ }^{55}$.

Inútil insistir longamente sobre a eleição do pai em Freud: ela já foi objeto de numerosos comentários. Invocarei simplesmente a versão "geológica" dessa argumentação - inspirada em Ferenczi - tal como é encontrada em Neuroses de transferência; uma síntese $e^{56}$ :

No principio era a abundância, o calor paradisíaco, o cumprimento do desejo; no principio era a terra-mãe, generosa, "capaz de satisfazer todas as necessidades". O pai só chega depois: inseparável do resfriamento glacial, contra o qual ele protege, cúmplice do despojamento da terra, da abstinência forçada. A separação do simples testemunho dos sentidos é uma passagem do quente para o frio, do prazer à realidade, de uma sexualidade sem entrave à privação ansiosa. Da mãe ao pai, do paraíso à glaciação, é menos da transição de uma configuração sexual à outra que se trata, mas mais de um movimento da sexualidade inteira uma sexualidade qualificada redundantemente, como se faz às vezes, como feminina.

\section{Sociedade parricida, sociedade incestuosa}

Os dois crimes edipianos estão na base da teorização freudiana do laço social. Mas, o que se conjuga na ordem individual - desejar a mãe/matar o pai -, se mantém separado na ordem coletiva. A cada um dos dois crimes, o parricídio e o incesto, corresponde um tipo diferente de socialidade.

A primeira teoria, aquela que formula Totem e tabu, é a mais freqüentemente apresentada como $a$ teoria freudiana do originário social. Ela é, ao menos, aquela pela qual Freud se "decide". O parricídio, sua culpa conseqüente, constituí-se em suporte. O outro crime está ausente. Há, sim, uma proibição do incesto, mas o que é assim proibido é menos o desejo e mais uma fonte eventual de divisão; o inter-dito é a letra de uma razão social prática ${ }^{57}$.

op. cit., p. 213.

56 op. cit., p. 33-38.

57 Poderíamos dizer da tese freudiana aquilo que escreve A. Green, comentando LéviStrauss - e Marie Delcourt: "tudo se passa como se não se pudesse falar da proibição do incesto e registrar seus efeitos senão no momento em que ela já silenciou sobre quem deve emudecer" ( Un oeil en trop, 1969, p. 247). 
O crime é, pois, o parricídio. Antes de ser interdito, a sua realização é obrigatória, como um imperativo fundador do estado de sociedade: para fundar a ordem social (ou uma ordem "nova"), matarás teu pai. De Júlio César a Luís XVI, passando por muitos outros, a história repete incansavelmente a mesma empresa. Os tempos modernos não escapam a isso: há assassinatos democráticos - Churchil, De Gaulle são bons exemplos ${ }^{58}$. O último dos "parricídios", em termos de data, não é o menos interessante; não bastou aos haitianos terem deposto o bando de filhos e mulheres reinantes - a esposa e a mãe-, ainda foi-lhes preciso assassinar o morto: saquear o túmulo do pai, quebrar o caixão e reduzir a cinzas os restos do tirano.

Da abundância ao despojamento glacial, o romance geológico evocado acima indicava uma coisa: a horda não está no principio, mas ela é um estado social relativamente tardio, contemporâneo do rigor dos tempos. Um indicador que testemunha melhor esse grau de elaboração: há mulheres, moças também - mas a relação pai-filho, anota Freud, somente mais tarde será conotada como incestuosa. Não há mãe, a começar pela mãe do pai: a "mãe" é paradoxalmente preservada ${ }^{59}$ pelo absoluto silêncio de que ela é objeto - podemos falar de uma filogênese do continente negro: "Os destinos da mulher nos tempos originários nos são ocultos por uma obscuridade especial"60.

O que descrevemos até o presente como sendo o amor homossexual entre o pai e os filhos mais velhos pode ser entendido de outro modo: não mais como um investimento de objeto, senão secundariamente, mas como barragem contra as armadilhas do "paraíso", em que o laço social se constrói como um negócio "entre homens", em meio ao desprezo ao feminino. Desse ponto de vista, há uma perda de sentido em apresentar os dois tipos de socialidade como encadeadas cronologicamente. Freud é forçado a isso pela forma "narrativa" de sua

58 É difícil atribuir apenas à "idade avançada" a sucessão rápida, em De Gaulle, da morte política e da morte real. Pensemos também na morte do Chá da Pérsia ou na paralisia de Nixon.

59 Evocando as divindades maternas, pela reparação, Freud indica que os sacerdotes que asseguravam o seu culto "foram castrados a fim de preservar a mãe segundo o exemplo que havia dado o pai da horda originária". Qual exemplo? aquele da castração dos filhos, é claro, mas também aquele de preservação da mãe. (cf. "Psychologie des foules...", op. cit., p. 207)

Vue d'ensemble..., op. cit., p. 44. 
teorização. Tratar-se-ia, melhor, de dois "momentos" contemporâneos e concorrentes, um retorcendo o outro até desfazê-lo.

Ausente da horda, o incesto está, ao contrário, no centro daquilo que pode ser, talvez um tanto prematuramente, chamado a segunda teoria de Freud, uma vez que ela permanece simplesmente como um esboço. Posto que estamos no originário, trata-se aqui do incesto materno: uma mãe e seu jovem filho. O acento posto sobre a idade não enfraquece em nada a força do crime: muito ao contrário, a violência do desejo incestuoso na criança não tem igual no adulto.

$\mathrm{Na}$ ordem social posta sob o signo do pai, o parricídio, antes de ser interdito, é um mandamento fundador. Não podemos, de forma alguma, estabelecer um paralelo no espaço matriarcal: o incesto está na fonte do dispositivo, sem poder dizer-se que está do mesmo modo que na ordem paterna - ainda menos pode-se afirmar que ele seja é ordenado.

No primeiro caso, a amplitude do tema parricida traduz-se pela desvalorização do crime incestuoso. Se o incesto está agora na origem, o parricídio acha-se menos desvalorizado em relação a ele do que inútil como um gesto que cai em desuso: morto o pai, ele é substituído. Insistamos sobre a importância de separar um pai que morre de um Pai Morto (ou seja, eterno) - aquele mesmo cujo retorno os filhos mais velhos desejavam.

Se, então, com a morte do pai (falo do moribundo e não do tirano), o filho protegido-preferido da mãe o substitui, isso indica uma coisa: uma "boa parte do poder" passa às mulheres, mas não todo. Não há sociedade, seja mesmo de regência materna, que não marque como masculino o fato social do poder ${ }^{61}$.

61 Dessa parte do poder, que transita do pai ao filho, pode-se deduzir que o filho em questão é o herdeiro do pai? Se quisermos, mas sob a condição de precisar que essa transição é um logro: o essencial se desloca a outro lugar, entre as mãos da rainha mãe.

Em um artigo intitulado "Le fils culturel" (In: L'écrit du temps, 1986, n. 12), P. Lacoste propõe para "o filho caçula" uma interpretação sensivelmente diferente da nossa. Segundo essa proposição, tal filho seria o protótipo do pai edipiano, o representante da terceira geração de sucessores do pai (artigo citado, p. 99-100). É difícil seguir esse autor por diversas razões:

- a eleição do mais novo dos filhos pelo desejo da mãe é já um ataque à transmissão paterna. A continuação indica claramente: o direito de primogenitura desprezado e a linha agnática afastada.

São os mais velhos que invocarão o pai - contra os privilégios do mais jovem. Uma invocação que supõe previamente a morte do pai, a devoração/identificação e o 
Evocando o reino das mulheres, Freud faz supor a proximidade de um risco, o perigo da confusão ${ }^{62}$. Podemos traduzir em termos de filosofia política o risco incorrido? A demanda dos filhos mais velhos é uma demanda de igualdade, e a pretensão do mais jovem é a do privilégio. O paradigma de todo privilégio será a possessão da mãe ? $^{63}$. "É permitido supor, escreve Freud, que o apego da grande nobreza ao "nascimento" não é senão uma relíquia desse antigo privilégio [o incesto como prerrogativa real] e observamos que, como conseqüência das uniões consangüíneas realizadas nas mais altas esferas sociais durante muitas gerações, as cabeças coroadas da Europa atual pertencem a uma ou a duas famílias somente"64.

O período da Revolução Francesa ofereceria, sem dúvida, um terreno propício à análise. A igualdade aí ocorreu como uma exigência quotidiana. Para além do humanismo como concepção, desvela-se aí a formação reativa, com toda a limpidez: toda cabeça que ultrapasse será cortada; as cabeças do Antigo Regime ou aquela que tentasse se reapropriar de seus favores.

reconhecimento da herança. Se Freud houvesse renunciado a essa vertente de sua teoria, não teria feito mais que repetir a tese de Atkinson - da qual a argumentação de P. Lacoste é bastante próxima.

- nas variantes freudianas da tese de Totem e tabu, há uma dupla modificação, cujos termos são solidários: não podemos separar a introdução do amor materno (o laço mãe/filho caçula) da nova concepção dos tempos que se seguem à morte do pai. Quando o amor materno é descartado, o governo das mulheres é negado, e ao ser introduzido, por Freud, o primeiro termo, a significação do direito se inverte, transformando-se no período do reino das mulheres. Em resumo: o filho caçula não é a primeira testemunha da transmissão paterna, mas o triunfo das mães - antes que esse ultimo seja totalmente eliminado.

Fiz, acima, alusão a Catarina de Médicis. Os períodos de regência têm geralmente uma reputação entre os historiadores. Do "reino" de Catarina dir-se-á, assim, que ele corresponde a um dos "períodos mais perturbados de nossa história". O julgamento crítico cede por vezes ao ódio: ela cheirava a morte, escreve Michelet, "seu marido instintivamente dela recuava, como de um verme, nascido da tumba da Itália". E, se ela dá à luz, é a um "rei apodrecido" (Francisco II), depois a um "louco" (Carlos IX, o "furioso" da São Bartolomeu) e, enfim, a um rei "agastado" (Henrique III e "o envilecimento" da França)... Mãe mortífera, rainha mãe

Possuir a mãe ou ser a sua única possessão? É a mãe quem protege e quem prefere. Quem, pois, deseja originalmente o incesto? 


\section{BIBLIOGRAFIA}

Adler \& Cartry (1971). La transgression et sa dérision. Em L'homme, Paris, 3(21).

Andre, J. (1987). L'inceste focal dans la famille noir antillaise. Paris: PUF.

Anzieu, D. La fantasmatique oral dans le group. Em Nouvelle revue de psychanalyse, (6), Paris: 1972.

Auge, M. Les métamorphoses du vampire. Em: Nouvelle revue de psychanalyse. n. 6, Paris: 1972.

Devereaux, G. (1972). « Considérations ethnopsychanalytiques sur la notion de parenté », Em Ethnopsychanalyse complémentariste. Paris : Flammarion,

Enriquez, E. (1983). De la horde primitive à l'état. Paris: Gallimard..

Fedida, P. (1972). Le cannibal mélancolique. Em Nouvelle revue de psychanalyse. n. 6, Paris.

Freeman, D. (1976). Totem e tabu, une nouvelle évaluation. Em L'anthropologie psychanalytique depuis totem et tabou. Sob a direção de MUENSTERBERGER, W.. Paris: Payot.

Freud, S. (1947). Totem et tabou. Paris, P. B. Payot.

Freud, S. (1981). Psychologie des foules et analyse du moi. Em Essais de psychanalyse, Paris: Payot.

Freud, S. (1951). Inhibition, symptôme et angoisse . Paris: PUF.

Freud, S. (1986). L'homme Moïse et la religion monothéiste. Paris: Gallimard.

Freud, S. (1986). L'homme Moïse et la religion monothéiste. Paris: Gallimard, nova tradução.

Freud, S.(1905). Trois essais sur la théorie de la sexualité. In: Idées. Paris: Gallimard,

Freud, S. (1975). Carta de 14-05-1912. Em Freud, Jung, Correspondance II. Paris: Gallimard.

Freud, S. (1979). La famille, In: Idées. Paris: Gallimard.

Freud, S. (1969). Manuscrit (31 mai 1897). Em La naissance de la psychanalyse. Paris: PUF.

Freud, S. (1987). Neuroses de transferência; uma síntese (manuscrito recém-descoberto). Organização, notas e ensaio complementar de Ilse Grubrich-Simitis. Tradução e pósfácio à edição brasileira de Abram Ackerman. Rio de Janeiro: Imago.

Freud, S. (1974). Obras Completas. S.. Trad. Luiz Lopez- Ballesteros, Espanha: Biblioteca Nueva.

Freud, S. (1986). Vue d'ensemble des névroses de transfert. Paris: Gallimard.

Granoff, W. (1975). Filiations, Paris: Minuit.

Green, A. (1972). Le cannibalisme: realité ou fantasme agi? Nouvelle revue de psychanalyse. Paris, (6).

Green, A. (1969). Un oeil en trop, Paris: Minuit.

Hart, C.W.M. \& Pilling, R. R. (1964). The Tiwi of North Australia. San Francisco: Holt, Rinehart 1 Winston.

Jones, E. (1956). The inception of Totem and tabou. Em Int. J. Psychoanal, (37). 
Jones, S. (1969). La vie e l'oeuvre de Sigmund Freud - III. Paris: PUF.

Lacan, J. Les complexes familiaux, Paris: Navarin.

Lacoste, P. (1986). Le fils culturel. Em L'écrit du temps.

Laplanche, J. (1980). Problematiques I, L'angoisse. Paris: PUF.

Leclaire, S. (1981). Rompre les charmes. Paris : Inter-Editions.

Levis-Strauss, C. (1985). La potière jalouse. Paris: Plon.

Levis-Strauss, C.( 1977). A identidade. O seminário de C. Lévi-Strauss. Paris: Grasset.

Levis-Strauss, C. (1949). Les structures élémentaires de la parenté (pp. 149). 1re édition, Paris: PUF.

Makarius, L e R. (1960). Prohibition de l'inceste et interdits alimentaires. Em Diogène. Paris: (30)

Moscovici, S. (1981). L'âge des foules. Paris: Fayard.

Roheim, G.( 1976). L' énigme du Sphinx. Paris: Payot.

Roustang, F.( 1981). Le mythe de l'Un. Em Confrontation; Le lien social. Paris.

Tylor, E. B. (1889). On a method of investigating the development of Institutions, applied to Laws of Marriage and Descent. .

Recebido em 20/03/00

Revisado em 20/05/00

Aceito em 31/05/00 